\title{
LIBERDADE, TRANSFORMAÇÃO, EMANCIPAÇÃO: QUAL O FIM DA EDUCAÇÃO?
}

\author{
Fernanda Bartoly Gonçalves de Lima ${ }^{1}$
}

\section{RESUMO}

O presente trabalho pretende discutir as bases históricas do ideário que atribui à educação certa responsabilidade pela liberdade do indivíduo, pela emancipação da humanidade, enfim, pela transformação do mundo social. Com uma revisão bibliográfica dos principais autores que influenciam no pensamento pedagógico contemporâneo, apresenta-se como se consolida a proposta burguesa de emancipação pela libertação individual, o que acarretaria numa transformação social. A partir daí, se discute o entendimento de liberdade e emancipação na perspectiva marxiana, que almeja uma revolução social como condição primeira para essas aspirações. Assim, uma pedagogia que se pretenda emancipadora não pode se furtar da discussão da superação do sistema social capitalista, compreendendo que é função da educação a formação do sujeito que compreende as raízes de sua alienação e a necessidade de uma transformação da realidade social, na qual seria possível à humanidade ser livre, emancipada. Desta forma, se conclui que não é possível para a educação realizar a libertação e consequente emancipação da humanidade, mas esta se apresenta como substancial para a criação de condições necessárias para se alcançar esse fim.

Palavras-chave: Pensamento pedagógico; Emancipação; Liberdade; Transformação social.

\section{FREEDOM, TRANSFORMATION, EMANCIPATION: WHAT IS THE PURPOSE OF EDUCATION?}

\begin{abstract}
This paper discusses the historical bases of the ideas that attach to education some responsibility for the individual freedom, for the mankind emancipation, finally, the transformation of the social world. With a bibliographic review of the main authors that influence on the contemporary pedagogical thought, it presents how the bourgeois proposal of emancipation by individual liberation is consolidated, which would result in social transformation. Thenceforth, it's discussed the understanding of freedom and emancipation in the marxian perspective, that envisions a social revolution as the first condition for these aspirations. Therefore, a pedagogy that aims to be emancipatory cannot avoid the discussion of overcoming the capitalist social system, understanding that is function of education the formation of the subject that comprising the roots of their alienation and the need for a transformation of the social reality in which could the mankind be free, emancipated. Thus, it is concluded that it is not possible for education perform the release and subsequent emancipation of humanity, but it is presented as substantial for the creation of conditions necessary to achieve this end.
\end{abstract}

Keywords: Pedagogical thought; Emancipation; Freedom; Social transformation. 


\section{Introdução}

A educação, ao longo da história, cumpre a função de desenvolver os seres humanos para uma determinada ordem social, promovendo a difusão de conhecimentos produzidos pela humanidade, considerados essenciais para sociedade na qual se insere. Assim, a estrutura social compõe uma das mais importantes determinações que incidem sobre a educação, e, dialeticamente, a educação cumpre a função de formar o ser humano, marcando sua possibilidade de intervenção no projeto de sociedade. No entanto, considerar a educação como um meio de se alterar questões relativas à sociedade ganha vigor junto ao pensamento moderno, a partir do século XVI, momento em que a própria estrutura social passa a ser questionada, não sendo mais esta uma ordem divina, e sim relativa à própria humanidade, podendo ser transformada por esta. Nesse contexto, a educação é alvo de uma grande expectativa: realizar transformações sociais, sendo as intencionalidades do tipo de ser humano que se deseja formar o norte do processo educativo.

Ideologicamente, a modernidade traz a possibilidade de a humanidade ser livre e emancipada ainda nesta vida - e não em uma existência futura - ao se restituir "[...] as temáticas e valores humano-sociais, após longo período de dogmatismo religioso da vida social, cultural e política" (LUIZ, 2006, p. 01). Transformações no modo de produção, movimentos mercantis, descobertas científicas, manifestações artísticas e reivindicações religiosas agenciam mudanças políticas e ideológicas, marcando o século XVI como o início do pensamento moderno do mundo ocidental. De acordo com Cambi (1999), este foi o século que começa a tomar corpo quase todas as características da modernidade: a secularização, o individualismo, o domínio da natureza, o Estado territorial e burocrático, a afirmação da burguesia, e da economia de mercado capitalista no sentido próprio. A concepção de ser humano, de infância e consequentemente de educação passam por uma revisão necessária para a nova proposta de organização social. A perspectiva humana que se instaura é daquele que quer conhecer e avançar, tendo como modelo o indivíduo que habita a cidade, nos burgos.

As transformações na forma de produção material, que passa de um padrão artesanal para a manufatura, geram uma evolução no processo de produção, aumentando a oferta de mercadorias disponíveis, que incidem num aquecimento do movimento mercantil. Dessa forma, há o crescimento da sociedade urbana, que faz com que sejam necessárias regras de civilidade, normas de comportamento, sendo a família não mais suficiente para essa questão, em um momento em que a Igreja Católica está sendo questionada pela Reforma protestante. Assim, urge a necessidade de uma institucionalização, regramento e ordenação do espaço educativo. A educação escolar para todos se instaura como um dos atributos necessário à modernização.

O momento se torna propício para a ascensão do grupo social burguês, que, pelo poder consequente de sua acumulação de capital, reivindica sua autonomia frente a padrões sociais antigos, que não mais correspondem com a nova realidade, na qual se vislumbra a possibilidade da humanidade vir a conhecer este mundo, e assim gozar da certa liberdade. A partir do momento em que a liberdade se vincula ao conhecimento, a educação é um dos pontos-chave para essa libertação. A educação é posta como a grande expectativa em prol da transformação social, a libertação do ser humano, e sua emancipação - uma proposta ambiciosa que se mantém atual nos projetos educacionais contemporâneos.

A ideia sobre a educação escolar ser uma forma de transformar a sociedade, de promover a liberdade, de fazer se alcançar a emancipação, continua fortemente presente nos discursos políticos, acadêmicos, e até mesmo no ideário do senso comum, porém, muitas 
vezes colocada como se o caminho entre o processo educativo e essas aspirações fossem naturalmente ocorrer. Falta clareza sobre qual seria a transformação social desejada, e talvez mais grave, os conceitos de liberdade e emancipação são trabalhados como se tivessem seus significados independentes de um contexto social, político e histórico.

Resgatando o sentido histórico do termo, Luiz (2006) afirma que emancipação, como utilizado na lei romana, designava a libertação de um filho da autoridade paterna, isto é, emancipação de relações patriarcais de obediência, submissão, dependência. Em contexto ao desenvolvimento dos ideais humanistas, a autora explica que o entendimento de emancipação se estende para o fim de qualquer obediência cega e de toda forma de coerção e ordem, reivindicando que a orientação da conduta individual provenha de mais ninguém além de si próprio. Portanto, entende-se que o ser humano livre de algo que o oprima, iniba, bloqueie ou o explore configura-se como condição para sua emancipação. A emancipação se completaria com a realização de uma plena liberdade. Como explica Fleck (2014, p. 179), "a emancipação sempre se refere a algo de que é preciso libertar-se. Insistir em uma emancipação da sociedade significa, portanto, que há coações sociais que impossibilitam a independência e autonomia das pessoas em determinada sociedade". A questão perpassa, portanto, pela indagação sobre o que nos oprime, qual condição que realiza uma inibição, bloqueio, ou ainda, a nossa exploração. E ainda, como esse tema passa a ocupar centralidade no discurso educacional.

Desta forma, o presente trabalho pretendeu elucidar de que forma a educação tem sido demarcada como esperança para a liberdade e emancipação da humanidade, como uma aposta para a transformação de uma realidade que apresenta problemas em sua composição social. Além disso, procura apresentar uma crítica ao entendimento de liberdade e emancipação, e uma necessidade de transformação social revolucionária, apontando perspectivas educacionais que coadunam com esta crítica.

Utilizando as categorias totalidade, contradição e mediação, buscou-se realizar uma análise bibliográfica a partir da perspectiva teórico-metodológica do materialismo histórico dialético. Assim, se perpassa as filosofias pedagógicas propostas por Comenius, Rousseau, Kant e Dewey, de forma a identificar suas concepções de liberdade e emancipação, e então compreender sua proposta de transformação social que se vincula ao projeto educativo. Esses pensadores foram escolhidos por serem os autores das principais ideias pedagógicas hegemônicas que foram sendo cooptadas e reelaboradas e, assim, estarem presentes no ideário pedagógico contemporâneo.

A partir daí, se contrapõe o entendimento de liberdade e emancipação fundamentado na concepção marxiana desses termos, ao resgatar a compreensão ontológica de humanidade. Utilizando textos clássicos de Marx e Engels, com os contemporâneos Duarte (1992), Iasi (2011), Lessa (2004), Netto (2009) entre outros, contesta-se a possibilidade de a humanidade ser livre e emancipada numa sociedade em que o trabalho é realizado de forma alienada. Dentro desta perspectiva, o problema da liberdade e emancipação se encontra nas bases materiais de produção social, o que cerceia o papel da educação na transformação social. No entanto, com base em Saviani (2005) e Duarte (1992, 2010), se mostra que a educação se configura como fator fundamental na formação do sujeito histórico, consciente de sua alienação e dos movimentos sociais que configuram a atual sociedade. Nesse sentido, se espera contribuir com a construção de um posicionamento consciente em relação às expectativas de liberdade, emancipação e transformação social que incidem sobre a educação. 


\section{Pensamento pedagógico moderno: a busca da liberdade}

O humanismo, movimento que inaugura a transferência de um pensamento teocentrista para o antropocentrista, demarca a possibilidade de formação do ser humano pelos próprios seres humanos, e da possibilidade de sua emancipação: “Como expressão do enfoque humanista, [...] tem-se a emancipação [...], caracterizando-se como uma demanda, como uma necessidade humana de emancipação de dogmas religiosos e de renascimento de valores humanos" (LUIZ, 2006, p. 02). A religião não é posta de lado, mas perde seu caráter monopolista do conhecimento. O ser humano passa a poder ser transformado pelo ser humano, pela via da educação. Como explica Suchodolski (2002, p. 13), "no processo histórico de desenvolvimento do pensamento pedagógico moderno, a prioridade pertence às concepções que atribuem à educação a função de realizar o que o homem deve ser. Como deve ser o homem?". As propostas pedagógicas modernas possuem como norte a formação do devir humano, o ser que irá representar a sintetização das mudanças necessárias para uma nova época.

Em meados do século XVII, Comenius (1592-1670) traz uma proposta de educação que, pela primeira vez, se direciona a todos, uma educação universal, com a publicação de Didactica Magna, conhecida como o Tratado da Arte Universal de Ensinar Tudo a Todos, em 1649. A viabilização de uma educação que seja para todos, e não apenas para uma classe privilegiada, implica na elaboração de procedimentos técnicos que permitam o barateamento dos custos de uma educação pública. Comenius, então, se ocupa em demonstrar sua possibilidade de efetivação por meio da simplificação do trabalho educativo: prévia organização dos objetos pedagógicos; estabelecimento de monitores e decuriões ${ }^{2}$ (que aumentariam significamente a capacidade de atendimento de alunos por um único professor); ordenação do conteúdo a ser ensinado dentro de uma lógica de rápida assimilação; e criação do manual didático, em substituição aos livros clássicos (lhe rendendo o título de idealizador do, hoje conhecido, livro didático). Como explica Alves (2001), a proposta de uma educação universal possui bases concretas numa aceleração, impessoalidade e desqualificação do ensino.

A marca medieval que prescindia de indivíduos com habilidades especiais para realizar um ofício, estava sendo substituída pelo desenvolvimento de materiais técnicos. Por exemplo, qualquer um poderia desenhar um círculo perfeito, contanto que estivesse de posse de um compasso. Assim, qualquer pessoa poderia realizar qualquer demanda, inclusive ser professor, a partir do desenvolvimento de materiais técnico-pedagógicos. Alves (2001) demonstra que essa concepção de educação inaugurada por Comenius possui íntima relação com a emergência de uma nova força produtiva, no contexto da superação do artesanato pela manufatura.

Logo, o educador morávio pressupunha uma organização para a atividade de ensino, no interior da escola, que visava equipará-la à ordem vigente das manufaturas, onde a divisão do trabalho permitia que diferentes operações, realizadas por trabalhadores distintos, se desenvolvessem de forma rigorosamente controlada, segundo um plano prévio e intencional que as articulava, para produzir mais resultados com economia de tempo, de fadiga e de recursos (ALVES, 2001, p. 73).

Portanto, a educação passa a ter propostas que não objetivam apenas a formação do indivíduo, mas também a produção material do mundo humano, sendo um importante instrumento para a implantação de uma nova sociedade. 
Dessa forma, a escola ajustava-se à nova época, na qual o conhecimento humano se tornara objetivo e o trabalho se objetivara por força da medição de instrumentos. Essa época, já anunciada por Bacon, seria a época da emancipação do homem pelo seu progressivo domínio da natureza; seria a época de produção das condições materiais que tornariam possível a igualdade dos homens (ALVES, 2001, p. 77, grifos do autor).

A concepção de emancipação do ser humano estava ligada ao desenvolvimento das condições materiais que permitissem determinada liberdade em relação às intempéries da natureza e que promovessem a produção de bens para a satisfação das necessidades dos seres humanos de forma mais simples e garantida. $\mathrm{O}$ desenvolvimento das forças produtivas significaria a libertação da humanidade das mazelas do antigo regime, incluindo a divisão dos seres humanos em níveis/classes sociais. Entendimento que permanece atual para a justificação do desenvolvimento do capitalismo.

Por ser a formação do ser humano pelo próprio ser humano o ponto crucial para se direcionar a sociedade para a transformação desejada, e essa nova sociedade significar a libertação da humanidade, a educação, enfïm, recebe seu aspecto salvacionista.

Portanto, na medida em que a cada um interessa a salvação dos seus próprios filhos, e àqueles que presidem às coisas humanas, no governo político e eclesiástico, interessa a salvação do gênero humano, apressemse a providenciar para que, desde cedo, as plantazinhas do céu comecem a ser plantadas, podadas e regadas, e a ser prudentemente formadas, para alcançarem eficazes progressos nos estudos, nos costumes e na piedade (COMÊNIO, 2001, p. 118).

A salvação da humanidade pela educação introduz uma mudança das expectativas que eram exclusivas de um locus religioso para um locus educativo. O desenvolvimento do ser humano é trazido para a própria humanidade.

A partir do século XVIII, o movimento iluminista arraiga a ideia de ser a humanidade, com sua racionalidade, a fonte de sua prosperidade. A passagem do capitalismo comercial para o capitalismo industrial, além de intensificar o inchaço urbano, permitiu a humanidade uma produção de bens em uma escala antes considerada impossível. A razão, a ciência e a tecnologia reafirmam a centralidade da humanidade em seu próprio progresso. Porém, o ideal humanista do iluminismo, por ter como base material estruturante o desenvolvimento das forças produtivas burguesas, fortalece o modelo liberal capitalista “" [...] dentro do qual a educação passou a desempenhar um papel muito importante, pois ela seria o único instrumento capaz de formar o cidadão para o novo regime" (ARCE, 2002, p. 30). Um novo regime abalizado pela redefinição das classes sociais.

Ariés (2006, p. 120) ilustra que, no século XVIII, houve "[...] a especialização social de dois tipos de ensino, um para o povo, e outro para as camadas burguesas e aristocráticas [...] os ricos foram separados dos pobres", demonstrando um processo de distinção do ambiente escolar: a educação é para todos, porém cada qual em seu lugar. Como explica Ariés (2006, p. 128):

Alguns deles, como Condorcet, permaneceram fiéis à ideia de um ensino universal aberto a todos. Mas a maioria propôs, ao contrário - a partir da expulsão dos jesuítas - limitar a uma única classe social o privilégio do 
ensino longo e clássico, e condenar o povo a um ensino inferior, exclusivamente prático.

O liberalismo reivindica o livre desenvolvimento da economia, a liberdade de possuir, defesa da livre concorrência, requerendo a limitação do poder estatal em benefício da liberdade individual, o que inclui a liberdade de ideias e crenças e sua livre expressão. $\mathrm{O}$ mercado livre seguindo seu caminho naturalmente traria crescimento e riqueza. Assim o ser humano também: deixá-lo livre para seu desenvolvimento natural seria a melhor forma de colher bons frutos para essa sociedade que se assinala.

Expoente da positividade natural do ser humano, Rousseau (1712-1778) elabora um tratado de educação que prioriza formar o ser humano natural livre, ao invés do cidadão "castrado" pela sociedade, trazendo uma proposta educacional de abordagem antropológica em detrimento a uma epistemológica. As ideias rousseaunianas partem da denúncia de que a vida social, na qual o ser humano era submetido, estaria em contradição com suas necessidades individuais. Essa noção de individualidade decorreu-se da decadência ideológica das explicações medievais, na qual lidava com uma vida cotidiana de menor prosperidade material. Com o crescimento da produção, o ideário que sustentava que o ser humano deveria suportar uma vida de sofrimento em prol de um bem maior, para uma recompensa além da vida, é questionado frente a uma realidade material de maior abundância. Passa a haver espaço para a indagação sobre quais seriam os interesses próprios do sujeito: reconhece-se o indivíduo. Dessa forma, se evidencia a contradição entre necessidades sociais, comuns a todos, e as necessidades individuais, os interesses particulares. Reconhecendo a urgência de se encontrar uma forma para que a coexistência social não seja inviabilizada pelos interesses individuais, Rousseau discorre sobre a necessidade de um contrato social. A cisão entre o indivíduo e sociedade é posta como remediável, mas não superável. Nesse sentido, o ser humano é um ser dual: o ser humano "natural" e o cidadão.

Na perspectiva de Rousseau, a educação do ser humano estaria gerando ambiguidade entre a formação do ser humano e a formação do cidadão, sendo essas incompatíveis. Assim, para o ser humano poder ser livre ele deveria ser formado para si mesmo, resgatando a prioridade da formação do ser humano integral, antes do cidadão, do produtor, do ser laboral. A valorização de uma vida privada, em contradição a uma pública, reforça o desenvolvimento de ideias individualistas, reflexo de uma cisão entre interesses particulares e interesses universais.

Quando, ao invés de educar um homem para si mesmo, se quer educá-lo para os outros? Então o acerto se faz impossível. Forçado a combater a natureza ou as instituições, cumpre optar entre fazer um homem ou um cidadão, porquanto não se pode fazer um e outro ao mesmo tempo (ROUSSEAU, 1995, p. 12).

Portanto, a educação é crucial para a formação do ser humano livre, mas deveria ser diferente do que havia sido até então. A ideia de um ser humano "natural" que deveria ser formado desde cedo para poder ser o mais livre possível dentro desta sociedade, traz a formação da criança como eixo central. A criança passa a ser vista como um ser em processo que precisa de cuidado desde cedo. Como explica Cury (2004, p. 09):

A educação e a criança tornam-se inseparáveis na medida em que a educação da criança é uma promessa de um progresso que inclua em si, desde logo, o sentimento e a afetividade. Nasce daí toda uma preocupação 
com essa fase da vida humana. A criança é vista como um potencial a ser desenvolvido pelos professores.

Estreia-se a afeição na educação da criança como parte do projeto para um futuro social melhor. A proposta rousseauniana de educação negativa instrui o mestre a interferir o menos possível no desenvolvimento próprio do jovem. "A educação - segundo Rousseau - não deve ter por objetivo a preparação da criança com vista ao futuro ou moldá-la de determinado modo; deve ser a própria vida da criança" (SUCHODOLSKI, 2002, p. 31). Afinal, o filósofo suíço vê, na sociedade, cerceamento e opressão, e preocupa-se em direcionar a educação como um fornecimento de assistência. Inaugura-se a centralidade do processo educativo no educando, perspectiva que foi posteriormente reeditada em diversos pensadores educacionais (Pestalozzi, Froebel, Hebart, Maria Montessori, Decroly, Claparéde, Dewey, entre outros). Rousseau evidencia uma falha da sociedade em garantir liberdade ao indivíduo, e recorre a uma reestruturação educativa como forma de contrapor o que percebe. Em sua proposta, a liberdade do ser humano assume um caráter plenamente individual, por meio de uma educação que se dá na esfera privada, para poucos.

Em contraproposta, Kant (1724-1804) via a liberdade e a natureza humana como opositores. $\mathrm{O}$ filósofo prussiano assume que a liberdade humana se estabelece quando se realiza a essência humana, sendo a essência humana a razão (KANT, 1999). Logo estar no reino da não-razão (da animalidade ou selvageria), apesar de estar se agindo livre das leis, o ser em si não seria livre, pois estaria preso ao mundo dos sentidos, dos caprichos, das vontades, o que o afastaria de sua humanidade. Para trazer o ser à sua essência humana, e consequentemente à sua liberdade, a educação teria o papel fundamental de coagir a criança a não ceder a suas vontades sem antes passar pelo crivo de sua própria razão. O objetivo de formação humana era se aproximar do seu eu transcendental, regido pela razão pura. Para Kant, "o indivíduo se tornará tão mais livre, mais humano, mais moral, quanto mais se aproximar do homo noumenon, isto é, quanto mais se tornar um ser que dirija suas ações pela razão pura" (DUARTE, 1992, p. 137). Nesse sentido a disciplina "se volta contra o estado selvagem de uma vontade que quer ser livre de qualquer lei, impedindo que o conceito de liberdade sem lei se fortaleça no processo de formação do ser humano" (DALBOSCO, 2004, p. 15).

Dalbosco (2004, p. 22) explica que, em Kant, a disciplina poderia conduzir à emancipação. Além disso, "o homem não pode se tornar um verdadeiro homem senão pela educação. Ele é aquilo que a educação dele faz" (KANT, 1999, p. 15). Assim a educação é a responsável pelo ser humano se tornar humano, e ainda, um ser humano emancipado. A emancipação é entendida, portanto, como a liberdade do ser humano decidir por sua própria razão o que é certo e o que é errado, e ainda a fazer o que é certo. A busca pelo desenvolvimento da razão humana poderia os aproximar, cada vez mais, desse eu transcendental, que expressa o ser humano livre e universal. Dessa forma, Kant vê na educação a salvação da humanidade, em que a cada experiência educativa de uma geração, esta se aperfeiçoaria, formando seres humanos cada vez melhores, até estes atingirem sua perfeitabilidade. Os indivíduos em sua perfeita humanidade seria a perfeição de toda a humanidade.

Ambrosini (2012, p. 379) verifica que Kant estabelece a ideia de emancipação enquanto saída da "menoridade" da humanidade, que seria cravada pela autonomia do sujeito em se guiar por si mesmo, por meio do uso da razão.

Não somente para a filosofia kantiana, mas para toda a sociedade moderna, pós Revolução Francesa (1789), a autonomia do sujeito é um princípio 
muito importante. Isso porque o sujeito, fazendo bom uso de sua racionalidade, pode superar a menoridade e construir o conhecimento científico, sem influência de crenças ou preconceitos, a fim de dominar e quantificar toda a realidade.

Essa autonomia não poderia ser realizada pelo sujeito individual, por suas próprias forças, mas sim pela coletividade, principalmente sendo concedida liberdade para esse fim: "percebe-se o acento no aspecto público, ou seja, o esclarecimento enquanto uma proposta coletiva para uma comunidade livre e não somente um desafio individual" (AMBROSINI, 2012, p. 380). Com destaque para o desenvolvimento individual pela coletividade, a educação se torna o local privilegiado para o esclarecimento da humanidade, para a construção de sua autonomia, e sua emancipação.

Isso porque o Iluminismo estabelece a educação como formadora do ser humano. A existência humana depende, para constituir-se como tal, de uma educação emancipadora. A educação adquire o significado não somente de transmitir habilidades e competências, mas de instruir para o exercício da cidadania, mais ainda, de formar a própria natureza humana (AMBROSINI, 2012, p. 381).

Diferentemente de Rousseau, que indicava formar para a natureza humana, Kant aspirar formar a natureza humana. Essa natureza se encontraria na ética e na moral, desenvolvidas pela racionalidade, contrapondo a ideia de uma boa natureza selvagem humana, que seria, na verdade, a sua prisão. Com os seres humanos sendo cada vez mais humanos, na concepção kantiana, a sociedade se tornaria cada vez mais próxima da perfeição humana. Dessa forma, a realidade objetiva seria alterada pela transformação da consciência dos indivíduos, não sendo o mundo concreto o impeditivo para a liberdade destes.

Os filósofos mencionados possuem extrema importância no indício de que a sociedade ainda não se encontrava no estágio desejado, e suas ideias trouxeram admiráveis reflexões sobre a humanidade, os qualificando como pensadores revolucionários em relação a seu contexto histórico-cultural. Não é à toa que seus conceitos serviram como base para inúmeras propostas pedagógicas que se inserem no espaço escolar ainda hoje. Porém “[...] a primazia recai nas condições subjetivas de alienação do sujeito, que podem ser resolvidas na consciência. Essa posição acaba se tornando suscetível à cooptação com uma aparente emancipação focalizada no indivíduo" (SILVA, 2008, p. 124).

Com um entendimento que a emancipação deve ser construída no interior de cada indivíduo, e que sua ação enquanto sujeito livre e emancipado, quando realizada por todos os indivíduos, significaria a emancipação de toda a humanidade, a educação é entendida como a grande aposta para a construção de uma sociedade que libertaria a humanidade de diferentes formas de sofrimento. Assim, a ideia de uma emancipação que depende do próprio indivíduo, sendo necessário apenas um Estado que, politicamente, não apresenta barreiras, se apresenta como a grande proposta da classe burguesa. Ressalta-se que a ascensão da burguesia, enquanto classe dominante, não poderia garantir a liberdade de forma igualitária. Desta forma, a liberdade da humanidade pela educação não poderia significar a liberdade de todos os seres humanos, pois a estrutura econômico-social se configura de forma a garantir sim o desenvolvimento da humanidade, mas de forma desigual em sua acessibilidade.

Sendo impossível negar a situação social alarmante da grande população, as ideologias que se enraízam a partir do século XVIII buscam explicar porque nem todos os seres humanos poderiam usufruir dos progressos da humanidade, incluindo a sua liberdade. 
O que impediria o indivíduo de ser livre, nestas ideologias, não seria ninguém mais do que ele mesmo. Os grilhões da humanidade se tornam invisíveis, porém não menos presentes. A explicação de alguns serem privilegiados em detrimentos de outros não é mais uma ordem divina externa aos seres humanos, como no antigo regime, mas uma ordem "divina" interna - os talentos individuais. As habilidades desenvolvidas por cada um não são percebidas como resultado de uma conjuntura social, mas como resultantes de capacidades que estariam presentes a priori no indivíduo.

Sendo a burguesia, até então, uma classe em busca de sua ascensão, sua ideologia liberal se mostra contraditória desde o início. Ainda enquanto uma classe revolucionária,

[...] fazia-se presente tanto seu lado ideológico progressista, de defesa da emancipação do ser humano, de crença na razão e na capacidade do homem construir sua história, como também se fazia presente seu lado ideológico mais reacionário, que apontava para a naturalização do social, para alienação das relações entre os seres humanos [...] (ARCE, 2002, p. 08).

Questões sociais como violência, vícios, corrupção, sucateamento do modo de vida, entre outras, aparecem como problemáticas dissociadas do modo de produção material, relegando ao indivíduo como um problema moral: nem todos possuem uma vida emancipada por sua própria responsabilidade.

Sobre as bases do modo de produção capitalista, a humanidade testemunhou um crescimento econômico sem precedentes, porém nunca igualitária, gerando a contradição entre alta produção e carência. Nas tentativas de explicar essa contradição (ainda vinculada a uma perspectiva de desigualdade por responsabilização individual) se entende que a escola está defasada em relação ao mundo produtivo. Dito de outra forma, a causa de ainda existir pobreza no mundo seria a falta de capacitação dos indivíduos para se incluírem no sistema social. Portanto, para resolver essa situação, tratava-se de reformar a educação.

É com este ideário que no século XX manifestam-se propostas educacionais preocupadas com a dissociação entre a educação e as necessidades da realidade social, enveredando o pensamento pedagógico para perspectivas pragmáticas, dentre as quais se destaca a do estadunidense Dewey (1859-1952). O pedagogo propõe os fundamentos de uma escola ativa, que representa sua esperança de alcançar a verdadeira democracia. "A sociedade almejada por Dewey é a democracia, um modo de vida cooperativo em que todas as definições advêm de consensos obtidos mediante livre e aberta participação de todos" (CUNHA, 2001, p. 89). Para isso, seria importante a formação do ser livre, que, segundo sua concepção,

Relativamente à liberdade, o importante é ter-se em mente que ela designa mais uma atitude mental do que a ausência de restrição exterior de movimentos, mas que esta qualidade espiritual não pode desenvolver-se sem grande produção de movimentos para os atos de explorar, experimentar, aplicar, etc. (DEWEY, 1959, p. 337).

O entendimento deweyano expressa o ideário liberal num contexto em que as barreiras políticas e econômicas, contra a qual a burguesia lutou, já estavam decaídas, no entanto a liberdade ainda não tinha sido alcançada por todos. Portanto, sua explicação se voltava para uma questão espiritual, condizente ao indivíduo, que precisava de uma formação diferente da tradicional, para construir esse estado de liberdade. Para isso, era preciso um processo de controle sobre uma suposta natureza humana. 
Já se presumiu, muitas vezes, explicita ou inconscientemente, que as tendências do indivíduo são, por seu natural, puramente individualistas ou egoístas, e, portanto, antissociais. Regulação ou controle denota então o processo pelo qual ele é levado a subordinar seus impulsos naturais aos fins públicos ou comuns (DEWEY, 1959, p. 25).

O trecho acima demonstra sua crença numa natureza humana que seria egoísta, e, portanto não passível de modificação, apenas de regulação. Porém, por meio da educação, cada indivíduo seria capaz se de autorregular, não sendo necessário um Estado regulador. Com indivíduos bem formados poderia se instituir o Estado democrático, onde a cooperação seria exercida plenamente e ofereceria iguais oportunidades de desenvolvimento a todos.

Dewey preconiza uma metodologia problematizadora, aprimorando o pensamento pragmático, como forma de assegurar um processo autônomo de construção do conhecimento do estudante, propondo uma ruptura com as condições sedimentadas da escola tradicional. Suas propostas educacionais demonstram a presença do ideário liberal, baseada na liberdade dos estudantes para elaborarem suas próprias certezas, seus próprios conhecimentos, suas próprias regras morais. A escola seria o instrumento central para o desenvolvimento da capacidade de cada um para sua vida em sociedade. Era crucial, portanto, ligar o que se era trabalhado na escola ao mundo real que estes deveriam enfrentar. Defende, portanto, a reconciliação entre a escola e a vida - não faria sentido um ensino que fosse realizado destacado das situações reais aos quais era requisitado. Havia o princípio de que os estudantes aprendem melhor quando realizam tarefas associadas aos conteúdos ensinados. Além disso, era substancial um ambiente de total autonomia para a construção do conhecimento por parte do estudante, relegando ao professor uma função mais voltada para a mediação. Dewey (1959, p. 179-180) assim sintetiza:

[...] primeiro, que o aluno esteja em uma verdadeira situação de experiência - que haja uma atividade contínua a interessá-lo por si mesma; segundo que um verdadeiro problema se desenvolva nesta situação como um estímulo para o ato de pensar; terceiro, que ele possua os conhecimentos informativos necessários para agir nessa situação e faça as observações necessárias para o mesmo fim; quarto, que lhe ocorram sugestões para a solução e que fique a cargo dele o desenvolvê-las de modo bem ordenado; quinto, que tenha oportunidades para por em prova suas ideias, aplicandoas, tornando-lhes clara a significação e descobrindo por si próprio o valor delas.

Apesar de se basear em formulações filosóficas rousseaunianas e kantianas, entre outras, Dewey critica a filosofia pedagógica do século XVIII por ser altamente individualista, mas reconhece que esta era inspirada pelo nobre ideal de uma sociedade cuja organização fomentasse o aperfeiçoamento de toda a humanidade. Dewey, então, se empossa de suas teorias, voltando para o aspecto do coletivo: o bem estar do coletivo se coloca como mais vantajoso do que os interesses individuais, quando estes se encontrarem em dissenso (assumindo que seria intrínseca a uma sociedade a contradição entre interesses individuais e o coletivo). Seu ideal de mundo se vincula, portanto, ao estado de bem estar social, porém cabendo à consciência de cada indivíduo o levar a agir em prol do bem estar coletivo.

Sobre as questões de classe, se preocupava em garantir a mobilidade social, pela educação: “[...] compete ao meio escolar contrabalançar os vários elementos do ambiente social e ter em vista dar a cada indivíduo oportunidade para fugir às limitações do grupo social em que nasceu, entrando em contato vital com um ambiente mais amplo" (DEWEY, 
1959, p. 22). Assim, ao aclamar uma sociedade mais justa e igualitária, coloca o indivíduo e suas capacidades como promotores desta. Mesmo demonstrando um profundo interesse na igualdade social, não propõe um modelo social que divirja do capitalismo. Sua proposta estabelece uma hierarquia democrática pela hierarquia das capacidades, ou seja, a meritocracia. Sua orientação escolar buscava a eliminação das questões de classe na escola, no entanto sem problematizar essas questões. Via, na educação, a possibilidade de elevar em todos os estudantes as capacidades necessárias para viver com dignidade. Sua tentativa era capacitar para que todos pudessem, harmonicamente, conviver, dando como consolidadas e irrevogáveis as bases econômico-sociais.

Sendo reproduzidos e reeditados por diversos autores, os projetos educacionais, acima apresentados, consolidam uma expectativa de transformação social por meio de uma educação que forme o ser humano livre, emancipado.

Essas esperanças fundamentavam-se na convicção de que as crianças cuja infância decorre numa boa atmosfera educativa em casa e na escola se tornarão homens de valor, homens equilibrados, capazes de reparar o mal deste mundo social onde terão que viver. Desempenhou aqui um papel decisivo o mito tradicional do renascimento social através da educação da nova geração (SUCHODOLSKI, 2002, p. 72).

A emancipação individual, como aposta para a concretização de uma sociedade melhor, se torna consenso nas propostas educacionais. Como explica Silva (2008, p. 97):

[...] a emancipação está relacionada ao crescimento individual e pessoal, baseada num sujeito abstrato, cujas mudanças passam por um posicionamento individual no qual a pessoa toma atitudes e "contamina" os outros à sua volta, provocando um círculo de mudanças, [...] emancipação significa a emancipação da consciência. A emancipação é autoemancipação. É o sujeito que tem de se emancipar. Já que não se pode mudar a sociedade, mude-se cada indivíduo.

Dado como óbvia uma concepção de emancipação como sendo o indivíduo autônomo, que toma suas próprias decisões, que é proativo (até mesmo empreendedor), a formação no modelo do indivíduo burguês bem-sucedido, e com carisma e solidariedade para com os mais "fracos", se torna meta educativa. Ganhando o título de "educação emancipatória", esta é responsabilizada para ser a realizadora de um mundo melhor. Enquanto a sociedade almejada não se concretiza, se perpetua o movimento de reformar a educação, com propostas que se anunciam como inovações, mas que mantém o modo de reprodução social burguês. As propostas pedagógicas se limitam a incidir sobre as metodologias educacionais, sobre o trabalho do professor, sobre o espaço escolar, sem estender o entendimento do fenômeno educativo para fora da escola.

Todavia, ainda quando em fase de consolidação da sociedade burguesa, Marx (1818$1883)$ e Engels (1820-1895) identificaram que o próprio sistema capitalista de produção se tornara o impeditivo para a realização plena da liberdade, para a emancipação humana. A liberdade burguesa nunca seria para todos.

\section{Liberalismo versus liberdade: por um pensamento pedagógico emancipador}

A ideia hegemônica moderna de emancipação se vinculou à liberdade econômica, jurídica, à igualdade de oportunidades, à cidadania, à meritocracia, podendo cada indivíduo 
construir sua emancipação dentro de um mundo em que, politicamente todos seriam iguais. Nessa perspectiva, a educação poderia propiciar a emancipação, pois com o conhecimento, com sua razão, o ser humano constrói livremente sua vida, que será boa ou ruim dependendo de suas capacidades e esforços individuais. Todavia, como explica Ambrosini (2012, p. 379), para Marx essa liberdade era "nada mais do que garantias para o individualismo e jamais para a emancipação humana". A proposta de libertação burguesa

[...] não é a revolução radical, a emancipação humana universal, mas a revolução parcial, meramente política, a revolução que deixa de pé os pilares do edifício. Em que se baseia uma revolução parcial, meramente política? No fato de que uma parte da sociedade civil se emancipa e alcança o domínio universal; que uma determinada classe, a partir da sua situação particular, realiza a emancipação universal da sociedade. Tal classe liberta a sociedade inteira, mas apenas sob o pressuposto de que toda a sociedade se encontre na situação de sua classe, portanto, por exemplo, de que ela possua ou possa facilmente adquirir dinheiro e cultura (MARX, 2010, p. 154).

Percebendo os limites do liberalismo burguês, Marx (2009) começa por assinalar a necessidade de qualificar a emancipação que está sendo proposta, afinal a reivindicação burguesa trata de uma emancipação política, na qual:

O Estado suprime, à sua maneira, a diferença do nascimento, do estado [social, Stand], da cultura, da ocupação [profissional, Beschäftigung], quando declara diferenças não políticas o nascimento, o estado, a cultura, a ocupação, quando (sem atender a estas diferenças) proclama cada membro do povo participante por igual da soberania popular [...] (MARX, 2009 , p. 49, grifos do autor).

A emancipação política se configura como uma emancipação das amarras das estratificações sociais, a abertura para alguma mobilidade social, alegando que não importa as condições de nascimento, ou de profissão, os indivíduos devem ser vistos em iguais condições perante o Estado. Porém: "[...] assim como os cristãos são iguais no céu e desiguais na terra, também os membros singulares do povo são iguais no céu de seu mundo político e desiguais na existência terrena da sociedade" (MARX, 2010, p. 97). A igualdade requerida perante o Estado legitima as desigualdades como um problema individual. A cisão entre o ser humano público e o ser humano privado acentua-se, sendo não mais a sociedade o impedimento da liberdade, mas sim cada indivíduo que é portador de seus próprios interesses particulares: certifica-se o egoísmo como parte da humanidade, de sua natureza.

A liberdade é, portanto, o direito de fazer e empreender tudo o que não prejudique nenhum outro. Os limites dentro dos quais cada um pode se mover sem prejuizo de outrem são determinados pela lei, tal como os limites de dois campos são determinados pela estaca [das cercas]. Trata-se da liberdade do homem como mônada isolada, virada sobre si própria. [...] o direito humano à liberdade não se baseia na vinculação do homem com o homem, mas, antes, no isolamento do homem relativamente ao homem. É o direito desse isolamento, o direito do indivíduo limitado, limitado a si. A aplicação prática do direito humano à liberdade é o direito humano à propriedade privada. [...] o direito do interesse próprio. 
Aquela liberdade individual, assim como esta aplicação dela, formam a base da propriedade civil. Ela faz com que cada homem encontre no outro homem, não a realização, mas antes a barreira da sua liberdade (MARX, 2009 , p. 64, grifos do autor).

Os outros indivíduos se tornam a própria limitação da liberdade de um indivíduo: o direito de cada um termina quando começa o direito do outro. A liberdade se ancora a elementos individuais, sendo a emancipação política o conjunto de sujeitos livres individualmente. Desta forma, a liberdade negativa do liberalismo, ou a retirada de barreiras públicas, não garante a realização da liberdade. Ao contrário, faz erigir barreiras individuais, na qual cada indivíduo deve proteger sua esfera privada de realização dessa "liberdade".

Ribeiro (2009, p. 425) em sua pesquisa dos escritos políticos marxianos a fim de elucidar os termos liberdade e emancipação, mostra que

A liberdade é transpassada dialeticamente pela contradição que opõe, do lado positivo, a consciência e, do negativo, as necessidades básicas determinadas pelas condições materiais de existência que ampliam ou limitam o exercício da liberdade. Como autodeterminação, a liberdade supõe, vista por um ângulo, a eliminação dos obstáculos que impedem a emancipação, ou seja, a realização de todo o potencial presente na pessoa humana [...]. Assim, em Marx e Engels a emancipação humana incorpora a liberdade, porém a supera ao incluir a dimensão natural e a social para além do indivíduo abstrato, no qual uma suposta razão, que seria superior, subordinaria as dimensões corporais e sociais. A liberdade é o fim projetado pelo capitalismo; por isso, é princípio da ação, com destaque para a liberdade de mercado que a crise iniciada em setembro de 2008, com a falência de bancos privados e bolsas de valores, mostra não ter sustentação material concreta. A falência do livre mercado condena, assim, milhões de seres humanos ao estado de não-liberdade, por estarem excluídos das condições objetivas/subjetivas mínimas de existência. A emancipação, por sua vez, é um projeto do socialismo, mas as poucas e recentes experiências, que datam do século XX, evidenciam a necessidade de aperfeiçoar esse projeto, para incorporar, na unidade social, a diversidade dos processos de organização e manifestação humanas.

Não se trata, portanto, de buscar a liberdade projetada pela ordem burguesa, que realizou a contradição entre a liberdade (de possuir) e a não-liberdade da grande massa populacional de satisfazer suas necessidades mais básicas. Nesse caminho se chegou a uma emancipação política, claramente insuficiente para a humanidade. Insuficiente, porém não dispensável: "A emancipação política é, sem dúvida, um grande progresso; ela não é, decerto, a última forma da emancipação humana, em geral, mas é a última forma da emancipação política no interior da ordem mundial até aqui” (MARX, 2009, p. 52, grifos do autor). Problematicamente, a emancipação política é vista como última forma de emancipação para a humanidade, a partir da perspectiva de que o capitalismo é a expressão social que corresponde à essência humana.

[...] a concepção liberal segundo a qual a permanência da ordem capitalista se deve ao fato de ela corresponder a uma pretensa "essência" humana. O homem seria, segundo esta concepção, de modo essencial e insuperável, um proprietário privado que se relaciona com os outros pela mediação dos seus interesses egoístas. [...] A contraposição teórica a esta falsa concepção 
apenas é possível através da mais profunda investigação acerca do que é ser humano (LESSA, 2004, p. 04).

Ao buscar superar o projeto de "liberdade" que culminou no Estado liberal com suas profundas contradições, se empenha aqui em resgatar o entendimento de emancipação humana. Para compreender como o ser humano pode ser plenamente emancipado é preciso antes entender o que é ser humano, a fim de se elucidar os equívocos sobre uma suposta natureza humana que seria egoísta, ou então sobre a existência de um indivíduo que seria anterior à existência da sociedade - crenças que explicam a sociedade burguesa como sendo a sociedade ideal, portanto última, insuperável. Neste sentido, a emancipação humana necessita ser compreendida a luz da concepção ontológica de humanidade.

O estudo ontológico da humanidade parte do questionamento sobre o que difere os seres humanos dos outros seres e, ainda, qual seria a essência humana. Sobre isto, Marx e Engels (2009, p. 24) elucidam que

Podemos distinguir os homens dos animais pela consciência, pela religião - por tudo o que se quiser. Mas eles começam a distinguir-se dos animais assim que começam a produzir os seus meios de subsistência (Lebensmittel), passo esse que é requerido pela sua organização corpórea. Ao produzirem os seus meios de subsistência, os homens produzem indiretamente a sua própria vida material.

Portanto, é a partir de sua atividade que o ser humano se difere dos outros animais. Mais especificamente, na sua atividade em relação à realidade que o cerca, a natureza a qual o ser humano faz parte, sendo esta uma atividade que realiza alterações nessa natureza, uma atividade que a transforma. Como explica Duarte (1992) os outros animais se adaptam à natureza, o ser humano adapta a natureza a si. Essa atividade de transformar a natureza, Marx e Engels a qualificam como trabalho. O primeiro ato histórico do ser humano não seria o ato de pensar, mas de começar a produzir seus meios de subsistência. "O trabalho [...] é a condição básica e fundamental de toda a vida humana [...] em tal grau que, até certo ponto, podemos afirmar que o trabalho criou o próprio homem" (ENGELS, 2013, p. 13). Trabalho seria então uma atividade exclusiva da humanidade, e ainda, a categoria ontológica do ser humano.

\begin{abstract}
Antes de tudo, o trabalho é um processo de que participam o homem e a natureza, processo em que o ser humano com sua própria ação impulsiona, regula e controla seu intercâmbio material com a natureza. Defronta-se com a natureza como uma de suas forças. Põe em movimento as forças naturais de seu corpo, braços e pernas, cabeça e mãos, a fim de apropriarse dos recursos da natureza, imprimindo-lhes forma útil à vida humana. Atuando assim sobre a natureza externa e modificando-a, ao mesmo tempo modifica sua própria natureza (MARX, 1989, p. 202).
\end{abstract}

O trabalho se configura como uma atividade de transformação do ser humano sobre a natureza. Sendo o ser humano integrante dessa mesma natureza, este se transforma neste processo, o que se entende por humanização. É importante destacar que, nesse processo, não se trata da hominização, que seria a evolução do ser humano enquanto espécie, mas sim de humanização, o desenvolvimento do ser humano enquanto gênero humano. 
No caso do ser humano, a mera sobrevivência física dos indivíduos e sua reprodução biológica através do nascimento dos seres humanos, assegura a continuidade da espécie biológica, mas não assegura a reprodução do gênero humano, com suas características historicamente constituídas (DUARTE, 1992, p. 24).

O ser humano se qualifica, assim, por dar existência a produtos que não foram criadas por uma força natural, mas por uma força própria humana, gerando capacidades, compreensões, atribuições que não são passadas biologicamente, mas devem ser feitas socialmente. Portanto, a o ato que dá vida ao gênero humano se configura como uma ação social, uma ação que destaca o ser de uma evolução natural para um ser social, que realiza o seu próprio desenvolvimento. Assim, a força humana é uma força social. O salto ontológico que forma o ser humano se configura como o surgimento do ser social: a humanidade e a sociedade são ontologicamente congêneres. Nesse sentido, a individualidade humana se funda na sociedade, de forma que é possível afirmar que sem sociedade não há indivíduo. Uma individualidade que preceda a sociedade é uma abstração equívoca, decorrente de configurações históricas que coloca o ser humano em oposição a outro ser humano, dando a falsa percepção de uma existência independente e contraditória entre indivíduo e sociedade.

Pelo contrário, a força social é a que permite o ser humano encontrar o reino da liberdade, na qual existe a possibilidade de escolher entre alternativas concretas. Na natureza não há possibilidades de escolhas, os caminhos possíveis já estão dados, são aqueles que garantem a sobrevivência de cada espécie. Desta forma, a liberdade existe apenas para o ser social, o ser que possui intencionalidade, que com sua atividade sobre a natureza redefine as alternativas para sua sobrevivência. E com isso, passa a ser possível exercer atividades que só podem ser realizadas quando o ser se encontra livre das obrigações físicas imediatas.

É verdade que também o animal produz. Constrói para si um ninho, habitações, como a abelha, castor, formiga etc. No entanto, produz apenas aquilo de que necessita imediatamente para si ou sua cria; produz unilateral [mente], enquanto o homem produz universal [mente]; o animal produz apenas sob o domínio da carência física imediata, enquanto o homem produz mesmo livre da carência física, e só produz, primeira e verdadeiramente, na [sua] liberdade [com relação] a ela; o animal só produz a si mesmo, enquanto o homem reproduz a natureza inteira; [no animal,] o seu produto pertence imediatamente ao seu corpo físico, enquanto o homem se defronta livre [mente] com o seu produto. $\mathrm{O}$ animal forma apenas segundo a medida e a carência da species à qual pertence, enquanto o homem sabe produzir segundo a medida de qualquer species, e sabe considerar, por toda a parte, a medida inerente ao objeto; o homem também forma, por isso, segundo as leis da beleza (MARX, 2008, p. 85).

Os pressupostos para uma emancipação humana estão presentes ontologicamente. $\mathrm{O}$ ser humano passa a transformar a natureza de acordo com suas necessidades, subjulgando o mundo a seu redor de acordo com sua vontade, dentro das suas capacidades históricas. $\mathrm{O}$ desenvolvimento da humanidade, percebido pelo decorrer da história, amplia as possibilidades concretas de escolha do ser humano, o que significa a expansão de sua liberdade. Analisando a atual sociedade capitalista, a humanidade tem a possibilidade de produzir todos os bens necessários à sua sobrevivência com maior facilidade relativa, e ainda produzir riquezas culturais que demarcam a infinitude do desenvolvimento humano. No entanto, tendo inerentemente como característica social a apropriação privada de bens 
humanos e, com isso, a desigualdade social, a organização social capitalista é marcada pela discrepância entre as possibilidades do gênero humano e a realidade de cada indivíduo. Por exemplo, apesar de a humanidade já ter produzido inúmeras formas de transportes, não são todos os indivíduos que podem decidir ir de um lugar para outro na forma mais fácil possível. De forma mais grave, apesar de a humanidade conseguir produzir alimentos suficientes para todos os seres humanos, muitos destes passam fome.

A ontológica relação entre o ser humano e a natureza, no capitalismo não pode ser realizado livremente: há um condicionante. A propriedade privada divide os seres humanos entre os donos dos meios de produção e os trabalhadores, grupo este que nada possui a não ser sua força de trabalho. Em um mundo onde é preciso trocar algo que se possui por algo que lhe é necessário, a força de trabalho torna-se mercadoria.

[...] o trabalhador baixa à condição de mercadoria e à de mais miserável mercadoria, que a miséria do trabalhador põe-se em relação inversa à potência (Macht) e à grandeza (Grôsse) da sua produção, que o resultado necessário da concorrência é a acumulação de capital em poucas mãos, portanto a mais tremenda restauração do monopólio, que no fim a diferença entre o capitalista e o rentista fundiário (Grundrentner) desaparece, assim como entre o agricultor e o trabalhador em manufatura, e que, no final das contas, toda a sociedade tem de decompor-se nas duas classes dos proprietários e dos trabalhadores sem propriedade (MARX, 2008, p.79, grifos do autor).

Para o trabalhador, o significado de sua ação perde a conexão com a ação em si, o seu trabalho passa a ser trabalho alienado. Como explica Duarte (1992, p. 25):

[...] as relações sociais capitalistas, nas quais o trabalho, a atividade vital, é transformada em mercadoria, essa atividade não se apresenta para o indivíduo como uma atividade na qual ele se objetive de forma humana, isto é, o trabalho alienado não deixa de ser uma atividade objetivadora, mas enquanto atividade transformada em mercadoria, sua realização tem para o trabalhador não o sentido de sua objetivação enquanto ser humano, enquanto ser pertencente ao gênero humano, mas sim o sentido de um meio (o único) que ele tem para assegurar sua existência.

Nesse sistema, "ser trabalhador produtivo não é nenhuma felicidade, mas azar" (MARX, 1989, p. 584). O trabalho se torna o contrário da liberdade, é então sua prisão. O trabalho, que ontologicamente funda a vida humana, passa a ser expropriação da vida:

O operário que durante doze horas tece, fia, fura, torneia, constrói, maneja a pá, entalha a pedra, transporta-a etc., considera essas suas doze horas de tecelagem, fiação, furação, de trabalho de torno e de pedreiro, de manejo da pá ou de entalhe da pedra como manifestação de sua vida, como sua vida? Muito pelo contrário. A vida para ele principia quando interrompe essa atividade, à mesa, no albergue, no leito. Em compensação, ele não tem a finalidade de tecer, de fiar, de furar etc., nas doze horas de trabalho, mas a finalidade de ganhar aquilo que lhe assegura mesa, albergue e leito. Se o bicho-da-seda tecesse para suprir sua exigência de lagarta, seria um perfeito assalariado. A força de trabalho nem sempre foi uma mercadoria. (MARX; ENGELS, 2011, p.31). 
Na sociedade capitalista, o trabalhador constrói um produto que não lhe pertencerá, e sim àquele cujo sua força de trabalho foi vendida. "O trabalhador trabalha sob o controle do capitalista, a quem pertence seu trabalho. [...] o produto é propriedade do capitalista, e não do produtor direto, do trabalhador" (MARX, 1996, p. 304). Para o trabalhador, o significado de sua ação perde a conexão com a ação em si, o seu trabalho passa a ser trabalho alienado. "Para ele próprio, o trabalho não faz parte de sua vida; é antes um sacrifício de sua vida. É uma mercadoria que adjudicou a um terceiro. Eis porque o produto de sua atividade não é também o objetivo de sua atividade" (MARX; ENGELS, 2011, p.30).

O trabalho alienado, como base estrutural desta forma societária, realiza a alienação do ser humano em diferentes níveis:

\begin{abstract}
Ao viver o trabalho alienado, o ser humano aliena-se da sua própria relação com a natureza, pois é através do trabalho que o ser humano se relaciona com a natureza, a humaniza e assim pode compreendê-la. Vivendo relações em que ele próprio se coisifica, onde o produto de seu trabalho lhe é estranho e que não lhe pertence, a natureza se distancia e se fetichiza.

Num segundo aspecto, o ser humano aliena-se da sua própria atividade. $\mathrm{O}$ trabalho deixa de ser a ação própria da vida para se converter num "meio de vida". Ele trabalha para outro, contrafeito, o trabalho não gera prazer, é a atividade imposta que gera sofrimento e aflição. Alienando-se da atividade que o humaniza, o ser humano se aliena de si próprio (autoalineação).

[...] Alienando-se de si próprio como ser humano, tornando-se coisa (o trabalho não me torna um ser humano, mas é algo que eu vendo para viver), o indivíduo afasta-se do vínculo que o une à espécie. Em vez de o trabalho tornar-se o elo do indivíduo com a humanidade, a produção social da vida, metamorfoseia-se num meio individual de garantir a própria sobrevivência particular (IASI, 2011, p. 21-22).
\end{abstract}

O autor acima demonstra os três aspectos da alienação: o ser humano está alienado (1) da natureza, (2) de si mesmo e (3) de sua espécie. Neste sentido, a emancipação humana, para além de conseguir sucesso individual, se refere ao fim alienação, ao fim da subordinação dos seres humanos a uma realidade criada pelos próprios seres humanos, que se volta contra eles como uma força estranha.

O desenvolvimento do trabalho, que deveria ampliar o potencial emancipador da humanidade, quando operado de forma alienada produz a sujeição do ser humano a uma realidade que é criada pela própria humanidade. As forças produtivas da humanidade lhe parecem estranhas, como se fossem forças sobrenaturais, que fogem de seu controle. $\mathrm{O}$ mundo criado pela humanidade não é percebido como pertencente ao ser humano que o constrói. Assim, a emancipação humana perpassa a necessidade de perceber que não há uma força mística, ou qualquer força externa que controla o mundo. A força que faz a realidade social é a força da própria humanidade. De forma mais clara Marx explica que

Só quando o homem individual retoma em si o cidadão abstrato e, como homem individual - na sua vida empírica, no seu trabalho individual, nas suas relações individuais -, se tornou ser genérico; só quando o homem reconheceu e organizou as suas forces propres [forças próprias] como forças sociais e, portanto, não separa mais de si a força social na figura da força política - [é] só então [que] está consumada a emancipação humana. (MARX, 2009, p. 71, grifos do autor). 
Trata-se, portanto, de revolucionar o modelo de produção existente, substituído este por uma forma de produção em que o trabalho possa ser realizado de forma emancipada. "A emancipação humana, transcendendo largamente a emancipação política, constituirá o programa do comunismo" (NETTO, 2009, p. 25, grifo do autor). O comunismo surge como o modelo social em que seria possível haver a emancipação humana. Coerente com a afirmativa de que as forças sociais são forças humanas, Marx (2010) elucida que a transição para o comunismo não se operaria por uma força sobre-humana e nem pelo indivíduo isolado, mas por uma classe social.

Onde se encontra, então, a possibilidade positiva de emancipação? Eis a nossa resposta: na formação de uma classe com grilhões radicais, de uma classe da sociedade civil que não seja uma classe da sociedade civil, de um estamento que seja a dissolução de todos os estamentos, de uma esfera que possua um caráter universal mediante seus sofrimentos universais e que não reivindique nenhum direito particular porque contra ela não se comete uma injustiça particular, mas a injustiça por excelência, [...]; uma esfera, por fim, que não pode se emancipar sem se emancipar de todas as outras esferas da sociedade e, com isso, sem emancipar todas essas esferas - uma esfera que é, numa palavra, a perda total da humanidade e que, portanto, só pode ganhar a si mesma por um reganho total do homem. Tal dissolução da sociedade, como um estamento particular, é o proletariado (MARX, 2010, p. 156, grifos do autor).

Na perspectiva marxiana, a emancipação da humanidade só pode ser realizada a partir da classe oprimida, a classe que vende sua força de trabalho em troca de salário, o proletariado. Não por uma reforma, mas por uma revolução social, que dissolveria todas as bases que constitui o capitalismo. Uma revolução liderada não por um coletivo formado por uma determinada educação, mas por uma classe que experimenta, na realidade de sua vida laboral, todas as contradições da proposta de liberdade do liberalismo burguês.

No entanto,

E assim, fica claro que não cabe à educação operar a emancipação da humanidade.

A arma da crítica não pode, é claro, substituir a crítica da arma, o poder material tem de ser derrubado pelo poder material, mas a teoria também se torna força material quando se apodera das massas. A teoria é capaz de se apoderar das massas tão logo demonstra ad hominem, e demonstra ad hominem tão logo se torna radical. Ser radical é agarrar a coisa pela raiz. Mas a raiz, para o homem, é o próprio homem (MARX, 2010, p. 151, grifos do autor).

A educação não ser capaz de promover uma mudança estrutural não implica sua total falta de perspectiva revolucionária. Não se considera que a educação pode realizar a emancipação da humanidade, mas pode criar condições necessárias para esse fim. De tal forma que a transformação da educação foi colocada como uma das principais metas para a instalação do modelo social soviético, na Rússia pós-revolucionária. Como explicam Bittar e Ferreira Jr (2015), a construção do sistema escolar após a Revolução de 1917 foram políticas praticadas em nome do socialismo. Afinal,

Era necessário criar novos programas que proporcionassem o conhecimento das leis básicas do desenvolvimento das ciências da natureza e da sociedade humana e, portanto, gerar uma nova racionalidade que fosse 
capaz de estabelecer as múltiplas e complexas conexões existentes entre os próprios homens e a natureza nos marcos da sociedade socialista, e, para isso, era essencial desenvolver diferentes métodos e formas organizativas do processo de ensino e de aprendizagem, o que possibilitaria estabelecer relações orgânicas entre a escola e a nova vida societária (BITTAR; FERREIRA JR, 2015, p. 439).

Entende-se, desta forma, que as expectativas de liberdade, emancipação, e ainda, transformação social cabem à educação numa perspectiva de formação de consciência crítica revolucionária. Nesse sentido, a educação deve estar comprometida com a formação do sujeito que compreende as raízes de sua alienação, e que se dispõe a não admitir a realidade social como imutável, que se entende enquanto ser em processo que faz parte de uma sociedade também em processo, logo que pode e deve ser revolucionada em coletivo pela exigência de uma humanização cada vez mais livre e universal.

Traduz-se, desta forma, a necessidade de uma verdadeira pedagogia emancipadora, ou seja, uma forma de se realizar a educação escolar comprometida com o projeto de emancipação humana. Compreendendo que se trata de uma emancipação defendida por Marx (2009), uma pedagogia emancipadora significa, portanto, uma teoria do (e para) o fazer pedagógico que tenha como referencial ontológico/epistemológico os fundamentos marxianos. Os ideais burgueses de indivíduo isolado, com uma essência egoísta, portador de interesses contraditórios em relação à sua sociedade não cabem a esse pensamento pedagógico. Logo, a relação do indivíduo com a sociedade não precisa ser contratual, pois a melhor expressão social não é a burguesa, mas justamente aquela em que os interesses do indivíduo não são conflitantes aos interesses do coletivo. Como explica Duarte (1992, p. 219-220),

Uma pedagogia fundamentada na teoria marxiana da história não pode aceitar a concepção de que o ser humano possua uma essência a-histórica, uma essência que regeria o processo histórico e a vida de cada ser humano, ou ainda uma essência natural, biológica, que seria desenvolvida ou reprimida pela vida em sociedade, etc. [...] uma pedagogia fundamentada numa concepção histórico-social do ser humano não poderia concordar com a ideia de que a possibilidade de um pleno desenvolvimento do indivíduo fosse pura e simplesmente uma questão de adequação dos métodos pedagógicos às características singulares de cada pessoa, que fosse, portanto, uma questão totalmente superável no âmbito interno à prática pedagógica.

Compreender que a educação não pode ser responsabilizada pela emancipação, liberdade e transformação social significa entender, também, que sem esta se anula qualquer perspectiva de mudança: Não é a educação a força motriz da história, mas a própria humanidade - humanidade esta que é desenvolvida em diversas esferas, dentre essas, no processo educacional. Como clarifica Saviani (2005, p. 13), cabe à educação, portanto, "produzir, em cada indivíduo singular, a humanidade que é produzida histórica e coletivamente pelo conjunto dos homens". O autor explica que a humanização, ou seja, a inserção do indivíduo humano em seu gênero, exige um processo de apropriação dos conhecimentos produzidos historicamente pela humanidade. Porém, sob a ordem social capitalista, que se baseia na posse e propriedade, o conhecimento não pode ser socializado publicamente e de forma igualitária, pois este também é utilizado como forma de dominação. 
Assim, a luta pelo comunismo coincide com a luta para que a escola efetive a sua função: socialização do conhecimento (SAVIANI; DUARTE, 2012).

Com esta compreensão, realizar, por meio da educação, a tarefa de ensinar os conhecimentos produzidos pela humanidade, promovendo a assimilação de suas raízes históricas, de forma que os estudantes se apropriem deste, já se configuraria como um movimento em prol da superação do capitalismo, e, consequentemente, em direção à emancipação humana. Essa função da educação parece óbvia, todavia, devido à contradição entre a função primordial da educação escolar e o modo de produção social em que esta se insere, o ato de ensinar algo a alguém tem sido escamoteado por inúmeras outras funções que têm sido relegadas à escola. Como explicam Saviani e Duarte (2012, p. 02-03) vivemos uma

[...] difusão de pedagogias que postulam para a escola todas as funções, menos a de transmissão sistemática de conhecimentos - entravam de todas as formas possíveis [...] [à] classe trabalhadora o acesso ao saber erudito. [...] O acesso ao conhecimento se dá de maneira profundamente desigual $\mathrm{e}$ seletiva. Tudo isso, entretanto, camuflado pelo discurso de respeito às diferenças culturais, pelo fetichismo da democratização do acesso ao conhecimento, espontaneamente assegurada pelas tecnologias de informação e [...] [por] uma lógica de permanente esforço do indivíduo para se adaptar às mudanças constantes das condições de vida e de trabalho $[\ldots]$.

A educação, radicalmente, é emancipadora, pois sua finalidade última é a humanização. No entanto, num sistema de dominação, o espaço educativo é utilizado para diversos outros fins que não a educação, do assistencialismo ao treinamento técnico.

O que se adverte é: as críticas à educação escolar que se realiza no sistema capitalista não invalidam a importância de uma instituição escolar, quando se pensa o desenvolvimento de uma sociedade mais justa e igualitária. A perspectiva marxiana de educação coincide com o processo educativo atual que cria e promove a escola como espaço destinado a esse fim: "Sua pretensão não é terminar com a escola para voltar a uma instrução natural [...] Marx e Engels não pretendem voltar atrás, mas sim ir em frente; não pretendem voltar ao artesanato, mas sim superar o capitalismo, e essa superação só pode se realizar a partir do próprio capitalismo, acentuando suas contradições, desenvolvendo suas possibilidades" (LOMBARDI, 2011, p. 11). A valorização dos avanços trazidos pela sociedade civil burguesa se clarifica na exposição de Duarte:

Uma sociedade comunista deve ser uma sociedade superior ao capitalismo e para tanto ela terá que incorporar tudo aquilo que, tendo sido produzido na sociedade capitalista, possa contribuir para o desenvolvimento do gênero humano, para o enriquecimento material e intelectual da vida de todos os seres humanos. Trata-se de: superar os limites do Iluminismo sem negar o caráter emancipatório do conhecimento e da razão; superar os limites da democracia burguesa sem negar a necessidade da política; superar os limites da ciência posta a serviço do capital sem, entretanto, negar o caráter indispensável da ciência para o desenvolvimento humano; superar a concepção burguesa de progresso social sem negar a possibilidade de fazer a sociedade progredir na direção de formas mais evoluídas de existência humana. Em termos pedagógicos, trata-se da superação das pedagogias negativas, ou seja, é necessário superar a educação escolar em suas formas burguesas sem negar a importância da 
transmissão, pela escola, dos conhecimentos mais desenvolvidos que já tenham sido produzidos pela humanidade. (DUARTE, 2010, p.48).

A educação possui um alcance limitado, mas fundamental, na instauração de uma sociedade que permita a emancipação humana. Por meio de uma pedagogia emancipadora, ainda nesta sociedade, é possível oportunizar que o indivíduo se aproprie dos patrimônios humanos, restabelecendo sua conexão com o gênero, favorecendo que este se relacione com os outros indivíduos não como opositores, e permitindo que este se identifique com todas as questões relativas a humanidade pelo simples fato de ser também um ser humano. No entanto, mesmo assim, na atividade ontológica humana, o trabalho ainda se realiza de forma alienada, no sentido que o indivíduo não tem o controle da produção dos bens que ele produz, e, da mesma forma, não tem pleno acesso a seus resultados. $O$ trabalho, para ele, ainda não é processo de sua autoconstrução, e sim apenas para suprir suas necessidades fisiológicas: o espaço para sua humanização só é encontrado quando seu expediente diário se encerra. Entretanto, por ter tido acesso a uma educação em que se realizaram aqueles momentos catárticos, passa a ser possível ao indivíduo ter consciência que seu trabalho, ainda alienado, é o que realiza o desenvolvimento da sua sociedade. E com essa consciência, se torna mais fácil perceber o mundo como de fato um mundo humanizado, ou seja, criado pelo ser humano e passível de ser transformado por este.

\section{Considerações finais}

A ideia de que existe uma forma de educação que poderia emancipar o indivíduo, cabendo à humanidade a descobrir essa "fórmula" educativa, se mostra como fruto do ideário capitalista. Devido à educação não ter cumprido essa aposta, vivemos, em nossa contemporaneidade, um momento de suspensão de todas as possibilidades de grandes projetos para a humanidade. Assim, para a voga pós-moderna, o fim da educação seria seu fim: não se acredita mais na possibilidade da educação intervir no projeto social. O próprio projeto social passa a estar sob suspensão, sendo o olhar voltado para o relativismo e soluções pontuais. Nesse ideário pós-moderno, cabe à educação se adequar às necessidades aparentemente subjetivas de cada um, sendo a aspiração de transformação social substituída por melhor acomodação de cada indivíduo ao "seu" mundo. Desiste-se do projeto emancipador, colocando-o como impossível de ser defendido em qualquer esfera, incluindo a esfera educativa, por acreditar que a emancipação seria em si uma proposta utópica, de impossível realização.

Neste sentido, o presente trabalho defende que a emancipação se torna inalcançável apenas a partir do momento em que não se admite a ruptura com o modo de produção capitalista. Ainda, ao contrário de desacreditar a função social da educação, por ela não ter realizado a emancipação do indivíduo, se aprofunda a crença na necessidade da educação para a criação de condições necessárias a transformação social. A educação descobrir um método "milagroso" de trazer a plena liberdade da humanidade não é uma expectativa quando se entende que o sujeito livre e emancipado requer uma sociedade que já rompeu com a admissão da propriedade privada, da divisão do trabalho, das classes sociais. A pedagogia emancipadora, no sentido de emancipação humana, se configura, assim, na formação do sujeito que possui uma profunda compreensão da realidade, de forma crítica e radical. Se não for a educação, o que poderá realizar essa formação? 


\section{Referências}

ALVES, G. Luiz. A produção da escola pública contemporânea. Campinas: Autores Associados, 2001.

AMBROSINI, Tiago Felipe. Educação e emancipação humana: uma fundamentação filosófica. Revista HISTEDBR On-line, Campinas, n.47, set. 2012. p. 378-391. Disponível em <https://www.fe.unicamp.br/revistas/ged/histedbr/article/view/4227/3431>. Acesso em 01 mar. 2016.

ARCE, Alessandra. A pedagogia na "era das revoluções": uma análise do pensamento de Pestalozzi e Froebel. Campinas: Autores Associados, 2002.

ARIÉS, Phillipe. História Social da Criança e da Família. Rio de janeiro: LTC editora. 2006.

BITTAR, Marisa; FERREIRA JR, Amarilio. Ativismo pedagógico e princípios da escola do trabalho nos primeiros tempos da educação soviética. Revista Brasileira de Educação, v.20, n. 61, p. 433-456, abr/jun 2015.

CAMBI, Franco. História da Pedagogia. São Paulo: Ed. Unesp, 1999.

COMÊNIO, João Amós. Didática Magna: tratado da arte universal de ensinar tudo a todos. eBook: Fundação Calouste Gulbenkian, 2001.

CUNHA, Marcus Vinícius da. John Dewey e o pensamento educacional brasileiro: a centralidade da noção de movimento. Rev. Bras. Educ. [online], n.17, mai/ago, 2001. p. 8699. Disponível em: < http://www.scielo.br/pdf/rbedu/n17/n17a06.pdf >. Acesso em 23 dez. 2015.

CURY, Carlos Roberto Jamil. Do iluminismo de Rousseau aos dias atuais. Revista Nova Escola. Edição Especial, São Paulo, dez. 2004. p. 09-12.

DALBOSCO, Cláudio Almir. Da pressão disciplinada à obrigação moral: esboço sobre o significado e o papel da pedagogia no pensamento de Kant. Educação \& Sociedade, Campinas, v. 25, n. 89, p. 1333-1356, set./dez. 2004.

DEWEY, John. Democracia e educação. São Paulo: Companhia Editora Nacional, 1959.

DUARTE, Newton. A formação do indivíduo e a objetivação do gênero humano (categorias iniciais de uma reflexão sobre o processo de formação do indivíduo numa perspectiva histórico-social). 1992. 238f. Tese (Doutorado em Educação) - Faculdade de Educação, Universidade Estadual de Campinas, Campinas, 1992.

DUARTE, Newton. O debate contemporâneo das teorias pedagógicas. In: MARTINS, Lígia Márcia; DUARTE, Newton. (Org.). Formação de professores: limites contemporâneos e alternativas necessárias. São Paulo: Cultura Acadêmica, 2010. 
ENGELS, Friedrich. Sobre o papel do trabalho na transformação do macaco em homem. In: ANTUNES, Ricardo (Org.) A dialética do trabalho: Escritos de Marx e Engels. 2 ed. São Paulo: Expressão popular, 2013.

FLECK, Amaro. Marx ou Habermas? Comentário crítico ao livro Marx e Habermas: Teoria crítica e os sentidos da emancipação, de Rúrion Melo. Cadernos de Filosofia Alemã. v. 19, n. 2, p. 165-181, jul/dez 2014.

IASI, Mauro Luis. Ensaios sobre consciência e emancipação. São Paulo: Expressão Popular, 2011.

KANT, Immanuel. Sobre a Pedagogia. Piracicaba: Editora Unimep, 1999.

LESSA, Sérgio. Para compreender a Ontologia de Lukács. Maceió: EDUFAL, 2004.

LOMBARDI, José Claudinei. Introdução. In: MARX, Karl; ENGELS, Friedrich. Textos sobre educação e ensino. Campinas: Navegando, 2011.

LUIZ, Danota Estrufika Cantoia. Emancipação e Modernidade: elementos para uma discussão. Serviço Social em Revista [online], v. 9, n. 1, jul/dez, 2006. p. 01-20. Disponível em: < http://www.uel.br/revistas/ssrevista/c-v9n1_danuta.htm>. Acesso em 16 dez. 2015.

MARX, Karl. O processo de trabalho e processo de produzir mais valia. In: $O$ Capital. Vol. I. Rio de Janeiro: Bertrand Brasil, 1989.

MARX, Karl. O Capital: crítica da economia política. Vol. I: O processo de produção do capital. São Paulo: Nova Cultural, 1996.

MARX, Karl. Manuscritos econômico-filosóficos. São Paulo: Boitempo editorial, 2008.

MARX, Karl. Para a questão judaica. São Paulo: Expressão popular, 2009.

MARX, Karl. Crítica da filosofia do direito de Hegel. São Paulo: Boitempo Editorial, 2010.

MARX, Karl; ENGELS, Friedrich. A ideologia alemã. São Paulo: Expressão Popular, 2009.

MARX, Karl; ENGELS, Friedrich. Textos sobre educação e ensino. Campinas: Navegando, 2011

NETTO, José Paulo. Prólogo à edição brasileira. In: MARX, Karl. Para a questão judaica. São Paulo: Expressão popular, 2009.

RIBEIRO, Marlene. Trabalho e educação no movimento camponês: liberdade ou emancipação? Revista Brasileira de Educação. v. 14 n. 42 set./dez. 2009. p. 423-439.

ROUSSEAU, Jean Jacques. Emílio ou da Educação. São Paulo: Martins, 1995.

SAVIANI, Dermeval. Pedagogia histórico-crítica: primeiras aproximações. Campinas: Autores Associados, 2005. 
SAVIANI, Dermeval; DUARTE, Newton (orgs.). Pedagogia histórico-crítica e luta de classes na educação escolar. Campinas-SP: Autores Associados, 2012.

SILVA, Kátia A. Curado P. Cordeiro da. Professores com formação stricto sensu e o desenvolvimento da pesquisa na educação básica da rede pública de Goiânia: realidades, entraves e possibilidades. 2008. 292 p. Tese (Doutorado em Educação) Faculdade de Educação, UFG, Goiânia, 2008.

SUCHODOLSKI, Bogdan. A pedagogia e as grandes correntes filosóficas: a pedagogia da essência e a pedagogia da existência. São Paulo: Centauro, 2002.

1 Doutoranda em Educação pela Universidade de Brasília (UnB), docente do Instituto Federal de Brasília (IFB).

${ }^{2}$ Decurião seria o aluno mais avançado de determinada turma, que conduz essa turma por encargo do professor.

Recebido: Abril/2016.

Aprovado: Março/2017. 